\title{
$\mathrm{ZrSe}_{2}$ の窒素雾囲気での焼結
}

田中嘉一郎・植月＼cjkstart徹・山 根 庸 史*・野 崎 善 治**・中 沢 泰 朗

$\left(\begin{array}{c}\text { 京都工芸繊維大学 工芸学部 無機材料工学科 } \\ * \text { 現在 }: \text { 本田技研工業(株) } \\ \text { ** 現在 }: \text { 大建工業(株) }\end{array}\right)$

$\mathrm{ZrSe}_{2}$ の焼結について, 窒素雾囲気中で, $800^{\circ} \sim 1450^{\circ} \mathrm{C}$ の温度範囲でホットプレス焼成と $1420^{\circ}$ 〜 $1480^{\circ} \mathrm{C}$ の温度範囲で等温通常焼成を行って調べた。 ホットプレスの出発原料には $\mathrm{ZrSe}_{2}$ と $\mathrm{ZrSe}_{3}$ をそれぞれ単独に化学輸送法により合成して使用した。

$\mathrm{ZrSe}_{3}$ はホットプレス中, $800^{\circ} \sim 1000^{\circ} \mathrm{C}$ の温度範囲で分解して $\mathrm{ZrSe}_{2}$ に移行した. $1150^{\circ} \mathrm{C}$ 以上 のホットプレスで, ち密化の進行と圧縮強さの増加が認められた. $\mathrm{ZrSe}_{3}$ を出発原料として, $1350^{\circ} \mathrm{C}$, 1 時間, プレス圧 $130 \mathrm{~kg} / \mathrm{cm}^{2}$ の条件でホットプレスを行った試片は, 最高の密度, 理論密度の $98 \%$ と最高の圧縮強さ, $1850 \mathrm{~kg} / \mathrm{cm}^{2}$ を示した。ホットプレスで $\mathrm{ZrSe}_{3}$ の分解を経て $\mathrm{ZrSe}_{2}$ の焼 結体を得る過程は活性化焼結法として応用できる.

$\mathrm{ZrSe}_{2}$ の等温通常焼成においては, 時間の経過に対する試片の収縮とち密化の進行が観測された. $\mathrm{ZrSe}_{2}$ の焼結の進行は Se 放出と, Se/Zr 比が減少する不定比化の進行を伴っていた.

焼結の過程はSe 離脱により生成する空格子を介した拡散により支配されると推察された。

(1985 年 7 月 31 日受付)

\section{Sintering of $\mathrm{ZrSe}_{2}$ in Nitrogen Atmosphere}

\author{
Kaichiro TANAKA, Toru UETSUKI, Youshi YAMANE*, \\ Yoshiharu NOZAKI** and Yasuro NAKAZAWA \\ Department of Inorganic Materials, Faculty of Engineering and Design, \\ Kyoto Institute of Technology \\ Matsugasaki, Sakyo-ku, Kyoto-shi 606 \\ * Present address: Honda Motor Co., Ltd. \\ ** Present address : Daiken Trade \& Industry Co., Ltd.
}

Sintering of $\mathrm{ZrSe}_{2}$ has been investigated by hot-pressing at $800^{\circ}-1450^{\circ} \mathrm{C}$ and by isothermal, normal sintering at $1420^{\circ}-1480^{\circ} \mathrm{C}$ in nitrogen atmosphere also. The starting materials, $\mathrm{ZrSe}_{2}$ and $\mathrm{ZrSe}_{3}$ were synthesized by a chemical-transport method. Decomposition and degradation of $\mathrm{ZrSe}_{3}$ into $\mathrm{ZrSe}_{2}$ with lower selenium content occurred during $800^{\circ}-1000^{\circ} \mathrm{C}$ in hot-pressing. Density and compressive strength of the sintered body increased on hot-pressing above $1150^{\circ} \mathrm{C}$. The compact started from $\mathrm{ZrSe}_{3}$ reached a maximum density, 98\% theoretical and a maximum compressive strength, $1850 \mathrm{~kg} / \mathrm{cm}^{2}$, under the hot-pressing conditions $: 1350^{\circ} \mathrm{C}, 130 \mathrm{~kg} / \mathrm{cm}^{2}, 1 \mathrm{~h}$. Degradation of $\mathrm{ZrSe}_{3}$ was applicable for an activated sintering in hot-pressing of $\mathrm{ZrSe}_{2}$. Shrinkage and densification occurred also in isothermal, normal sintering of $\mathrm{ZrSe}_{2}$. Progress in sintering of $\mathrm{ZrSe}_{2}$ was accompanied with release of Se and with increase in non-stoichiometry in $\mathrm{ZrSe}_{2}$ to lesser $\mathrm{Se} / \mathrm{Zr}$ ratio. It was suggested that the sintering process of $\mathrm{ZrSe}_{2}$ was governed by diffusion mechanisms.

[Received July 31, 1985]

Key-words : Sintering, $\mathrm{ZrSe}_{2}, \mathrm{ZrSe}_{3}$, Non-stoichiometry, Nitrogen atmosphere

\section{1. 緒言}

$\mathrm{Zr}-\mathrm{Se}$ 系化合物については, 1950 年代後半に Hahn

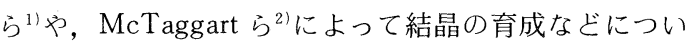

て報告された。その後, $\mathrm{ZrSe}_{3}$ については, Krönert ら ${ }^{3)}$ によって構造解析, Brattås ら ${ }^{4)}$ にって $\mathrm{ZrX}_{3}(\mathrm{X}:$ 力 ルコゲン）型結晶構造をとる化合物の典型として報告さ 
れた. $\mathrm{ZrSe}_{2}$ については, Gleizes ら5) によって非化学量 論性について報告された. 応用面では, $\mathrm{ZrSe}_{3}, \mathrm{ZrSe}_{2}$ が鎖状及び層状の結晶構造をもつことから，インター カーレーションを利用したリチウム電池など ${ }^{6), 71}$ に注目 されている. しかし，Zr-Se 系化合物は共有結合性が高 く難焼結性であると考えられるが，焼結性を含めた高温 での挙動についてはほとんど報告されていない。

本研究では, $\mathrm{Zr}-\mathrm{Se}$ 系化合物のうち, $\mathrm{ZrSe}_{3}$ と $\mathrm{ZrSe}_{2}$ を単独に合成して, それぞれの粉末圧密体について窒素


は，一部，等温における通常焼成も行って高温における 挙動や焼結性について検討した。

\section{2. 実 験}

\section{1 試料の合成}

試料結晶の合成はヨウ素を輸送材に用いた閉管式化学 輸送法で行った。ジルコニウムは純度 $99.9 \%$ のメタル シートを細く切断して使用した。セレニウムとヨウ素は 純度 $99.999 \%$ の化学試薬を使用した。手順は, 一端を 封じた内径 $10 \mathrm{~mm}$ の石英ガラス管を用い，所定の配合 比に配合した原料と，管内容積 $1 \mathrm{~cm}^{3}$ あたり $5 \mathrm{mg}$ のヨ ウ素を加えて, 一端を冷却しながら $1 \times 10^{-5}$ Torr まで 脱気した後, 約 $24 \mathrm{~cm}$ の長さに封じ切って反応管を作 製した. 合成は, $16^{\circ} \mathrm{C} / \mathrm{h}$ で $650^{\circ} \mathrm{C}$ まで予備加熱をした 後, 温度こう配のある管状炬に移し, 反応管両端の温度 を高温側 $950^{\circ} \mathrm{C}$, 低温側 $800^{\circ} \mathrm{C}$ に保って 7 日間反応さ せて行った。

\section{2 焼 成}

合成で得られた試料は，メノウ乳鉢で粉砕して，100 メッシュの笠を通過させた後, $1000 \mathrm{~kg} / \mathrm{cm}^{2}$ の圧力で, 直径 $6 \mathrm{~mm}$, 高さ $6 \mathrm{~mm}$ の円柱に予備成形した.

ホットプレス焼成は，試片を黒鉛の型に入れ，黒鉛の 押し棒により, 昇温, 保持, 冷却の過程を通して, 130 $\mathrm{kg} / \mathrm{cm}^{2}$ の静圧を加えて, $4^{\circ} \mathrm{C} / \mathrm{min}$ で昇温, 所定の温度 で 1 時間保持した後炉内放冷を行った。炉内に導入する 窒素は， $180^{\circ} \mathrm{C}$ 及び $400^{\circ} \mathrm{C}$ に加熱した活性化銅と還元 銅の槽を通過させて脱酸素を行った。

等温における通常焼成は, 試片を外径 $10 \mathrm{~mm}$ のアル ミナ管に装てんした後,一端から窒素を導入し, 所定の 温度に保持した炉内にアルミナ管ごと出し入れする方法 で焼成と冷却を行った。アルミナ管の装入に際しては, 炬内の温度分布を利用して, $600^{\circ}, 800^{\circ}, 1000^{\circ} \mathrm{C}$ の各 温度で 10 分間予熱を行い, 所定の温度で 6 分間の立ち あがり時間を取った。

\section{3 測 定}

$\mathrm{ZrSe}_{3}$ の粉末 X線回折ピークの指数付けは, 格子定数 の粗い值を用いて観測值に対して指数付けを行い, 更に, 格子定数を最小二乗法で精密化した。精密化の計算は,
計算機プログラム, UNICS-RLC 3 を使用して, 京都 大学FACOM-230-60 で行った。

$\mathrm{ZrSe}_{2}$ の格子定数は, 内部標準物質に純度 $99.99 \%$ の 金属ケイ素を用いて, $\mathrm{ZrSe}_{2}$ 面指数 (102), (003), (110), (103)，(004)，(211)，(114）の各回折線から測定した. 計算は $\mathrm{ZrSe}_{3}$ と同じプログラムを使用した.

粉末 X線回折による定量分析は, 内部標準物質にケイ 素を用いて面指数 $\mathrm{ZrSe}_{3}$ (112), (004) と, $\mathrm{ZrSe}_{2}$ (102), (003) と, Si (311) の回折線の積分強度比より測定し た。

蛍光 X線分析による定量分析は, 合成で得た $\mathrm{ZrSe}_{3}$ 結晶を標準物質として，相対的な定量値を求めた．測定 は, ターゲットに Snを使用して, Se $10.84<11.60 \mathrm{keV}$, Zr 15.32<16.20 keVで行った.

密度の測定は，ケロシンを浸液とする液中ひょう量法 によりかさ密度を測定した。浸液のケロシンの比重は温 度補正を行った。相対密度の算出は, Brattås ら ${ }^{4)} の$ $\mathrm{ZrSe}_{3} d_{\text {obs. }}=5.71$ と McTaggart ら ${ }^{2)}$ の $\mathrm{ZrSe}_{2} d_{\text {obs. }}=$ 5.48 の実測真比重を基準にして行った. 不定比化進行 に伴う真比重変化に対しては補正は行っていない。

圧縮強さの測定は，オートグラフのクロスヘッドス ピード $0.5 \mathrm{~mm} / \mathrm{min}$ で行った.

\section{3. 実験結果と考察}

合成により得た結晶の走査型電子顕微鏡 (SEM) 像 を図 1 に示す. $\mathrm{ZrSe}_{3}$ は銀灰色リボン状で単斜晶系に属 する結晶である. 表 1 に粉末 X線回折ピークに指数付け を行った結果を示す。格子定数は, Brattås ら ${ }^{4)}$ の結果, $a=5.411 \AA, \quad b=3.749 \AA, c=9.444 \AA, \beta=97.48^{\circ}$ 之 良く一致した。 $\mathrm{ZrSe}_{2}$ は六角板状, 淡緑色の結晶で六方 晶系 $\mathrm{CdI}_{2}$ 型である.

図 2 は，ホットプレス焼成による結晶相の変化を粉末 X線回折による定量分析で求めた結果である.ここで, 以下, 出発原料に $\mathrm{ZrSe}_{3}$ を使用した試片を $\mathrm{E}-3, \mathrm{ZrSe}_{2}$ を出発原料にした試片を E-2 と称する. E-3では, $850^{\circ} \sim 1000^{\circ} \mathrm{C}$ の間で $\mathrm{ZrSe}_{3}$ から $\mathrm{ZrSe}_{2}$ へ相変化してい る.これは $\mathrm{ZrSe}_{3}$ が高温で不安定であり, Se を放出し て分解するが，その過程で新たに $\mathrm{ZrSe}_{2}$ が晶出してく るものと思われる. $\mathrm{ZrSe}_{3}$ 単独相のままで焼結するため には本実験の条件では不十分で, 高温で Se 蒸気圧を高 く保つ必要があると思われる。 $\mathrm{ZrSe}_{2}$ 相は本実験の条件 では $1500^{\circ} \mathrm{C}$ 付近まで安定で, それ以上の高温では $\mathrm{Se}$ を放出して $\mathrm{Zr}_{2} \mathrm{Se}_{3}$ 相への移行がみられる. 図3にホッ トプレス焼成を行った試片の密度の変化を示した． E-3 は $900^{\circ} \mathrm{C}$ 付近で相変化に伴う密度の低下がみられる. $1050^{\circ} \mathrm{C}$ 付近から両試片ともに密度が上昇し， $1350^{\circ} \mathrm{C}$ 以 上で相対密度は最高 $98 \%$ 程度に達する. 圧縮強さの変 化を図 4 に示した. $\mathrm{ZrSe}_{2}$ は $\mathrm{CdI}_{2}$ 型の層状の結晶構造 


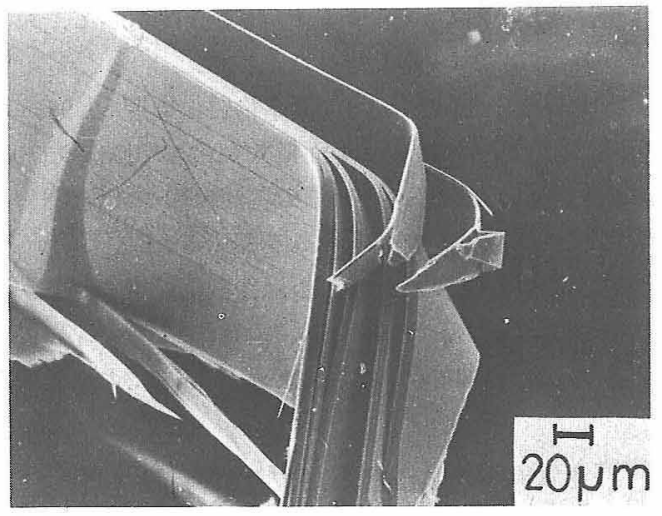

( a )

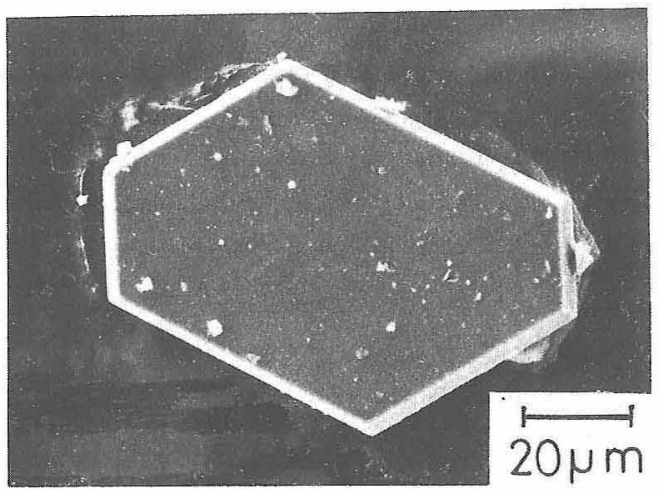

(b)

Fig. 1. SEM photographs of synthesized (a) $\mathrm{ZrSe}_{3}$, (b) $2 \mathrm{rSe}_{2}$.

Table 1. Calculated and observed spacings of synthesized $\mathrm{ZrSe}_{3}$.

\begin{tabular}{|c|c|c|c|c|}
\hline h & k & 1 & d. ob s. & $d, c a \mid c$. \\
\hline 0 & 0 & 1 & 9.368 & 9.361 \\
\hline 0 & 0 & 2 & 4.681 & 4. 681 \\
\hline 0 & 0 & 3 & 3.125 & 3.120 \\
\hline 0 & 1 & 2 & 2.928 & 2.926 \\
\hline 1 & 1 & 2 & 2.483 & 2.485 \\
\hline 0 & 0 & 4 & 2.341 & 2. 340 \\
\hline 1 & 0 & 4 & 2.050 & 2.050 \\
\hline 0 & 1 & 4 & 1.986 & 1.985 \\
\hline 0 & 0 & 5 & 1.872 & 1.872 \\
\hline \pm 1 & 0 & $\mp 5$ & 1.846 & 1. 843 \\
\hline 1 & 2 & 1 & 1.728 & 1. 725 \\
\hline 1 & 0 & 5 & 1.702 & 1. 700 \\
\hline 0 & 1 & 5 & 1. 675 & 1.675 \\
\hline 0 & 0 & 6 & 1. 561 & 1.560 \\
\hline 3 & 0 & 4 & 1. 338 & 1. 339 \\
\hline 2 & 2 & 3 & & 1. 339 \\
\hline 1 & 3 & 1 & 1.202 & 1.202 \\
\hline 0 & 0 & 8 & 1. 170 & 1.170 \\
\hline 0 & 1 & 8 & 1.117 & 1.117 \\
\hline 2 & 3 & 1 & & 1.117 \\
\hline 3 & 2 & 5 & 1.020 & 1.020 \\
\hline 0 & 0 & 10 & 0.936 & 0.936 \\
\hline 3 & 0 & 8 & 0.926 & 0.926 \\
\hline 0 & 1 & 10 & 0.908 & 0.908 \\
\hline \multicolumn{5}{|c|}{ 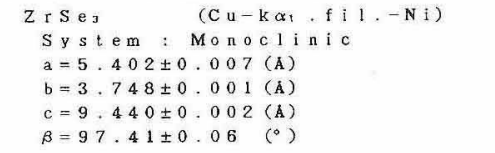 } \\
\hline
\end{tabular}
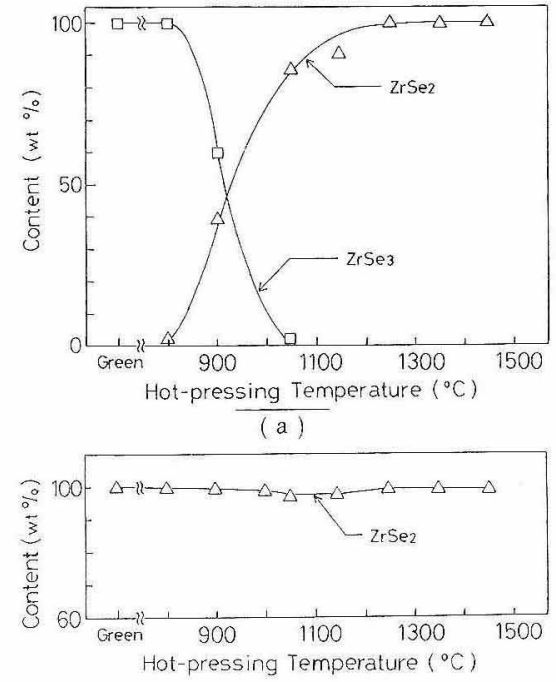

(b)

Fig. 2. Change of crystal phase compositions with hot-pressing temperature for the compacts started from (a) $\mathrm{ZrSe}_{3}: \mathrm{E}-3$ and (b) $\mathrm{ZrSe}_{2}:$ E-2 (hot-pressing time $: 1 \mathrm{~h}$ ).

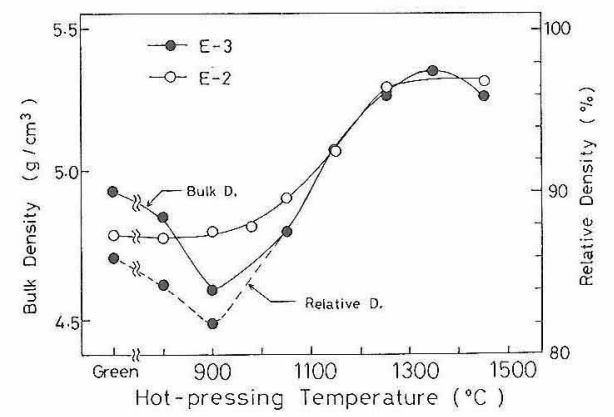

Fig. 3. Change of densities with hot-pressing temperature for the compacts started from $\mathrm{ZrSe}_{3}: \mathrm{E}-3$ and $\mathrm{ZrSe}_{2}$ : E-2 (hot-pressing time : $1 \mathrm{~h}$ ).

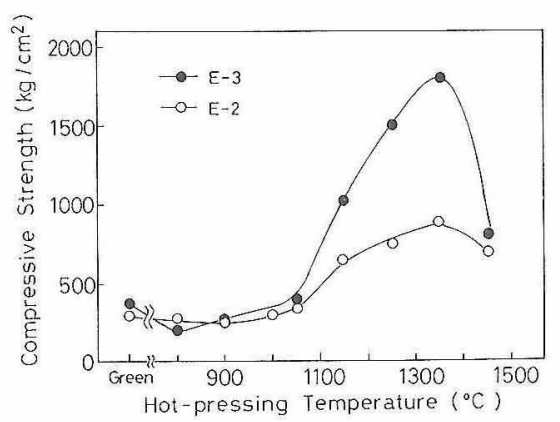

Fig. 4. Change of compressive-strength with hotpressing temperature for the compacts started from $\mathrm{ZrSe}_{3}: \mathrm{E}-3$ and $\mathrm{ZrSe}_{2}: \mathrm{E}-2$ (hot-pressing time $: 1 \mathrm{~h}$ ).

を取るので絶対的な強さは大きいものではない. $1150^{\circ} \mathrm{C}$ 付近から増加がみられ $1350^{\circ} \mathrm{C}$ で最高值を示す

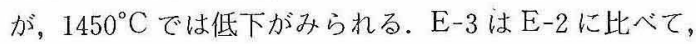
高温で焼成した場合，圧縮強さは大きく最高で 1850 
$\mathrm{kg} / \mathrm{cm}^{2}$ を示した．圧縮強さは，微構造の変化も原因し ている上考えられる. 図 5 に焼成体の破断面の SEM 像

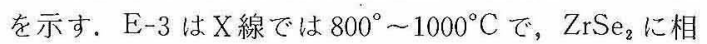
変化しているが，外形的には $1050^{\circ} \mathrm{C}$ 付近でもりボン状 の $\mathrm{ZrSe}_{3}$ 構造に見える。 $1350^{\circ} \mathrm{C}$ では明らかにこれとは

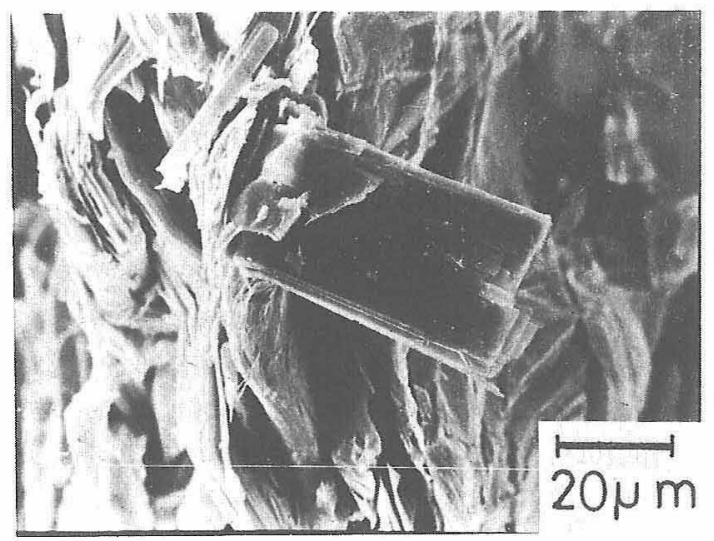

$$
\mathrm{E}-3900^{\circ} \mathrm{C}
$$

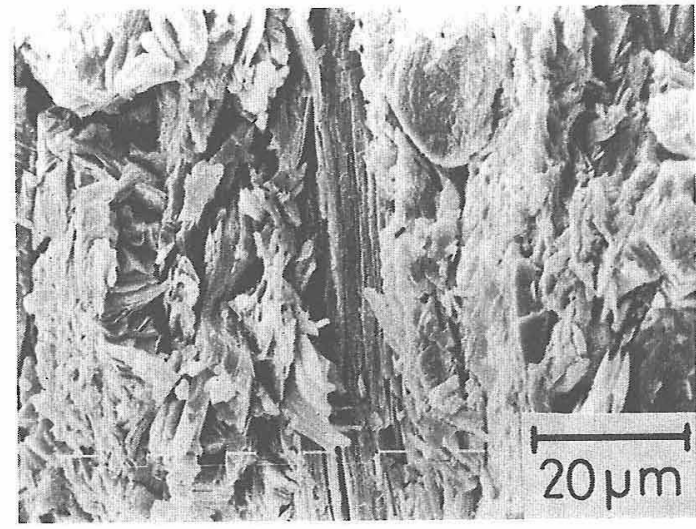

$$
\mathrm{E}-31050^{\circ} \mathrm{C}
$$

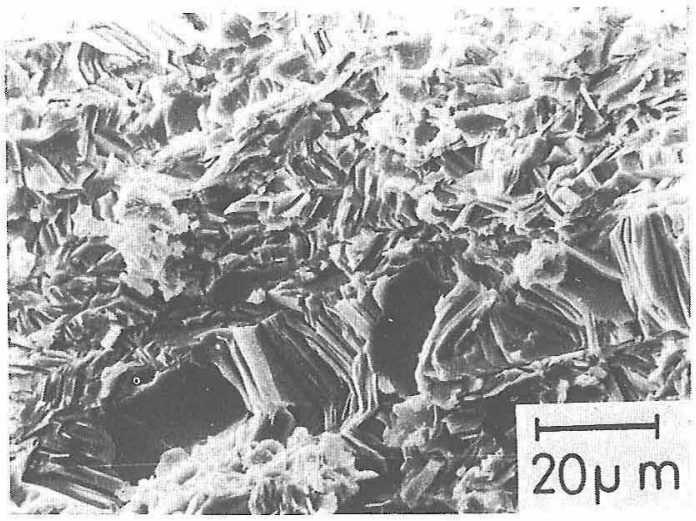

$$
\mathrm{E}-31350^{\circ} \mathrm{C}
$$

異なった $\mathrm{ZrSe}_{2}$ の細かな層状の結晶でち密な組織が構 成されていることが分かる，一方，E-2では組織が最 初から大きな板状の $\mathrm{ZrSe}_{2}$ 結晶で構成されているのが 分かる。 $1350^{\circ} \mathrm{C}$ では層構造が更に発達しているように 見える。このことから， $\mathrm{ZrSe}_{3}$ が分解して $\mathrm{ZrSe}_{2}$ が生成
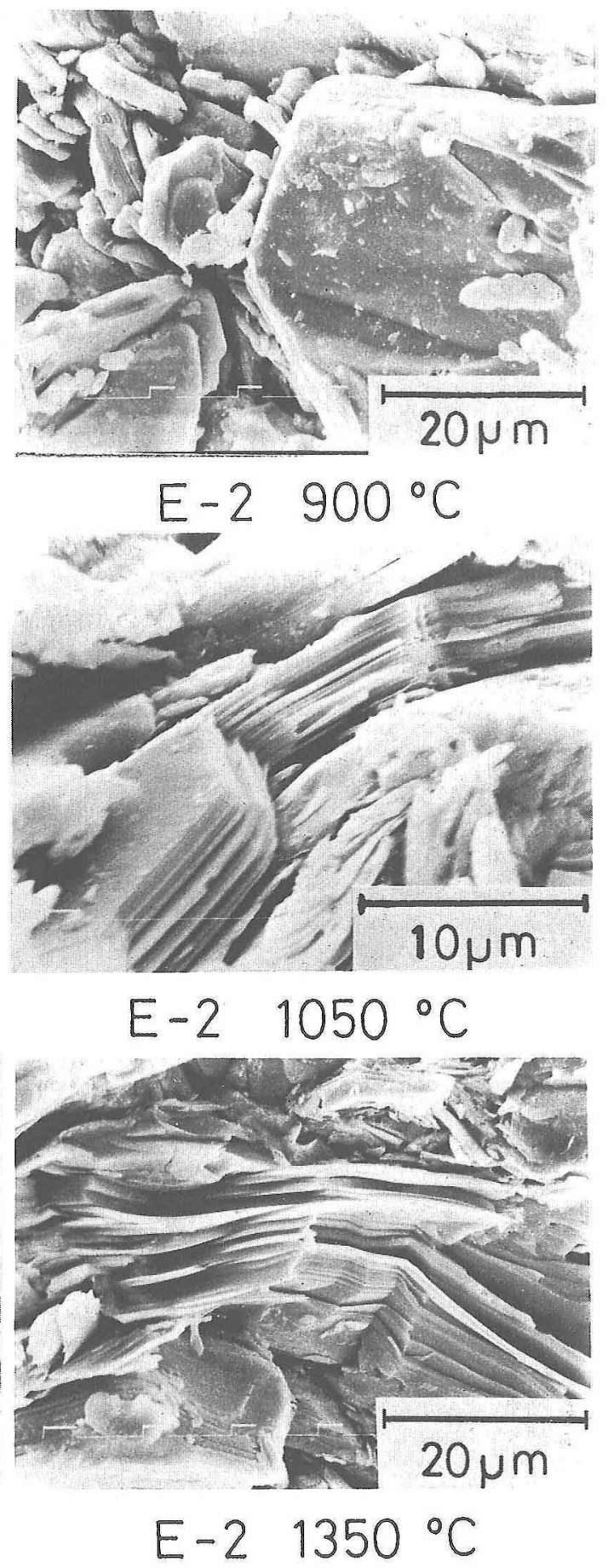

Fig. 5. SEM photographs of fractured surface of hotpressed compacts started from $\mathrm{ZrSe}_{3}: \mathrm{E}-3$ and $\mathrm{ZrSe}_{2}: \mathrm{E}-2$ at shown temperatures (hot-pressing time $: 1 \mathrm{~h}$ ). 
する際，微細な単位から成長してくると思われる．E-3 の $1350^{\circ} \mathrm{C}$ 焼成の試片が最も強い圧縮強さを持つのはこ のためであろう. また $1450^{\circ} \mathrm{C}$ の試片は粒成長のため組 織は粗大になっている. 圧縮強さの低下がみられるのは このためと考えられる.

次に, 焼成の際の $\mathrm{Se}$ の離脱に伴う不定比化の進行を みるために, 図 6 に蛍光 $\mathrm{X}$ 線分析による $\mathrm{Se} / \mathrm{Zr}$ 比と図 7 に $\mathrm{rSe}_{2}$ の格子定数の変化を示す. $\mathrm{E}-3$ では, $\mathrm{ZrSe}_{3}$ の分解に伴って $1050^{\circ} \mathrm{C}$ 付近まで $\mathrm{Se} / \mathrm{Zr}$ 比の連続的な低 下がみられる．E-2 の Se/Zr 比は $1000^{\circ} \mathrm{C}$ 付近から上で 1.85 程度に下がってくる. 格子定数は, 両試片とも $1150^{\circ} \mathrm{C}$ 付近から $a$ 軸減少 $c$ 軸増加の傾向がみられる. この結果は, Gleizes ら ${ }^{5)}$ にる報告, $\mathrm{ZrSe}_{2}$ の不定比化 合物合成において, $\mathrm{Se} / \mathrm{Zr}$ 比減少に伴って $a$ 軸減少, $c$ 軸増加が起こった結果と符合するものである.

以上のホットプレス焼成の結果から, $1150^{\circ} \mathrm{C}$ 以上で はち密化の進行, 圧縮強さの増加より焼結が進行してい ると判断され, 同時に $\mathrm{ZrSe}_{2}$ の不定比化の進行も伴っ ていることが分かる. また, $\mathrm{E}-3$ における $\mathrm{ZrSe}_{3}$ の分 解を経て $\mathrm{ZrSe}_{2}$ の焼結体を得る過程は, 一種の活性化 焼結と考えることができる. 図 8 に通常焼成法による等 温焼成実験の結果を示した. 図 8(a) は試片の直径方向 の線収縮率と時間の関係を両対数軸にプロットしたもの

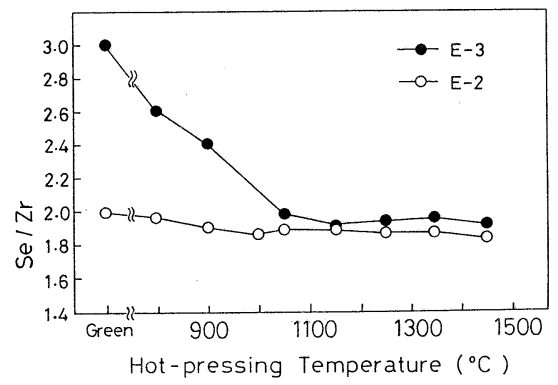

Fig. 6. Change of $\mathrm{Se} / \mathrm{Zr}$ ratio with hot-pressing temperature for the compacts started from $\mathrm{ZrSe}_{3}: \mathrm{E}-3$ and $\mathrm{ZrSe}_{2}$ : E-2 by fluorescence X-ray analysis (hotpressing time $: 1 \mathrm{~h}$ ).

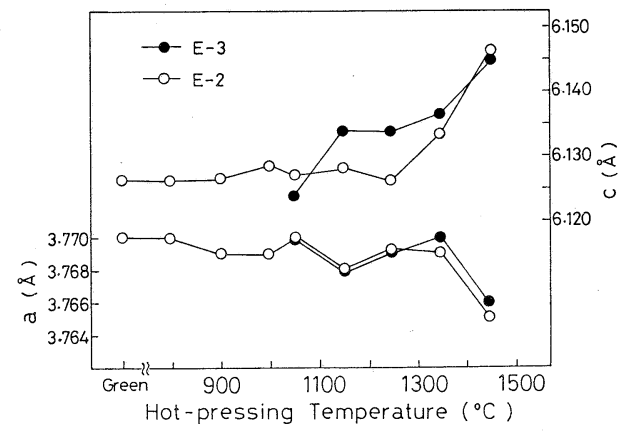

Fig. 7. Change of lattice parameters of $\mathrm{ZrSe}_{2}$ with hot-pressing temperature for the compacts started from $\mathrm{ZrSe}_{3}: \mathrm{E}-3$ and $\mathrm{ZrSe}_{2}: \mathrm{E}-2$ (hot-pressing time $: 1 \mathrm{~h}$ ).
である．試片は，急激加熱による初期膨張の影響を受け たため全収縮率は大きくはないが，収縮は時間の経過と ともに進行している. 直線の大体のこう配は，1/5 2/5 である. 図 8(b) に密度の変化を示した. 初期膨張の影 響は受けるが, 時間の経過に対するち密化の進行がみら れる. 図 8(c) に格子定数の変化を示した. $1480^{\circ} \mathrm{C}, 40$ 分付近で, $a=3.766 \AA, c=6.145 \AA$ を取る.この值は ほぼ限界值と考えられ, Gleizes ら ${ }^{5)}$ の結果 $a_{\min }=$ $3.7674, c_{\max }=6.150 \AA, n=\mathrm{Se} / \mathrm{Zr}=1.851$ と符合して いる.

以上の実験結果をまとめて次の 2 点から焼結の機構を 考察すると, (1) 焼結の過程で格子定数の変化する不 定比化が進行した（2）等温での通常焼成において, 試片の時間の経過に対する収縮とち密化が進行した.

$\mathrm{ZrSe}_{2}$ は $\mathrm{CdI}_{2}$ 型の結晶構造で一層おきにファンデル

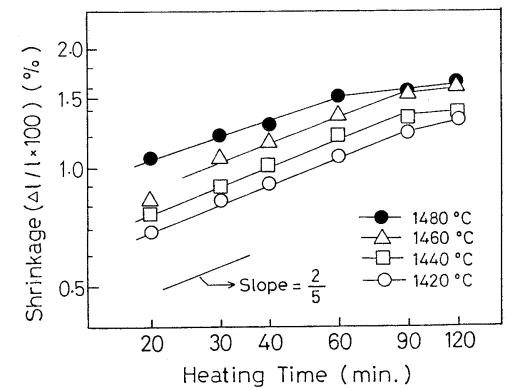

(a)

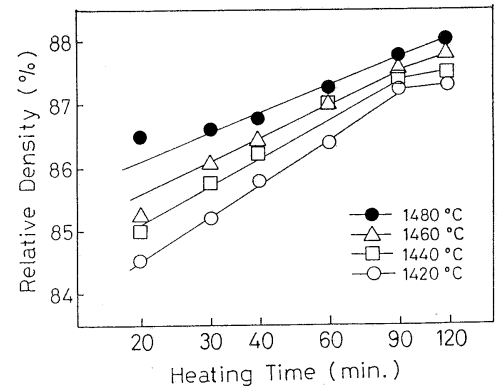

( b )



(c)

Fig. 8. Changes of (a) shrinkage, (b) relative density and (c) lattice parameters with sintering time for $\mathrm{ZrSe}_{2}$ at various temperatures under isothermal, normal (pressure-less) sintering. 
ワールスカで結ばれている Se-Se 層を持つ. Se/Zr 比 の低下に対する格子定数の変化, $a$ 軸減少, $c$ 軸増加に 対して, Gleizes ら5) は特殊なモデルとして(1)Se 空格子 の生成, (2) Se 空格子位置への $\mathrm{Zr}$ の侵入，によるとして $\mathrm{Se}-\mathrm{Se}$ 層間への $\mathrm{Zr}$ の侵入がないモデルを提出してい る. 本実験の結果も同様の傾向を示し, Se の離脱によ り空格子が生成し, 空格子を介した Se, Zr 搪散が起 こったことにより, 同モデルのような格子定数変化を起 こしたと考えることができる. 実験では拡散の経路は明 らかではないが, Se-Se 層間の結合力は弱く, bulk 内 でもこの層（層壁も含めて）を介しての拡散は容易であ ると仮定すると表面以外の経路の拡散，体積拡散なざも 可能であると考えられる. 拡散により粒子間距離が収縮 するモデルとしては, Kingery $ら^{8)}$ の体積拡散モデルを はじめ多くの報告がある. 図8(a) の直線のこう配は Kingery $ら^{8)}$ の体積拡散のモデルと一致する. 現段階で は $\mathrm{ZrSe}_{2}$ 内の $\mathrm{Zr}$ 原子と $\mathrm{Se}$ 原子の拡散の経路や速度に 関しては明らかでないので, モデル式を直接適用して解 析するのは困難であると思われるが更に詳細な実験と検 討が必要である.

以上の実験結果と考察より, 焼結の進行は Se 離脱に より生成する空格子を介した Se 及び Z r の拡散により 支配されると推察された。

\section{4. 結 言}

$\mathrm{ZrSe}_{3}$ 及び $\mathrm{ZrSe}_{2}$ を用いて, 窒素雾囲気中 $800^{\circ} \sim$ $1450^{\circ} \mathrm{C}$ でホットプレスを行った。また $\mathrm{ZrSe}_{2}$ は， $1420^{\circ}$ $\sim 1480^{\circ} \mathrm{C}$ で等温における通常焼成も試みた。 その結果 は,

(1) $\mathrm{ZrSe}_{3}$ は 1 気圧窒素雾囲気では, $800^{\circ} \sim 1000^{\circ} \mathrm{C}$ で分解して $\mathrm{ZrSe}_{2}$ に移行する.

（2） ホットプレスで $\mathrm{ZrSe}_{2}$ の，ち密で強固な焼結 体を得る場合，（1）の過程は活性化焼結法として応用 でき, 出発原料に $\mathrm{ZrSe}_{3}$ を使用すると有利である.

( 3 ) $\mathrm{ZrSe}_{2}$ の焼結の進行はSe の離脱により生成す る空格子を介した Se 及び Z r 原子の拡散により支配さ れると推察された。

\section{文献}

1) H. Hahn and P. Ness, Z. Anorg. Allgem. Chem。, 302, 37-49 (1959).

2) F. K. McTaggart and A. D. Wadsley, Aust. J. Chem., 11, 445-86 (1959).

3) W. Krönert and K. Plieth, Z. Anorg. Allgem. Chem., 336, 207-18 (1965).

4) L. Brattås and A. Kjekshus, Acta Chem. Scand., 26, 3441-49 (1970).

5) A. Gleizes and Y. Jeannin, J. Solid State Chem., 1, 180-84 (1970).

6) M.S. Whittingham and F. R. Gamble Jr., Mater. Res. Bull. , 10, 367-72 (1975).

7) Y. Onuki, R. Inada, S. Tanuma, S. Yamanaka and H. Kamimura, Japan. J. Appl. Phys., 20, 1583-88 (1981).

8) W. D. Kingery and M. Berg, J. Appl. Phys., 26, 1205-12 (1955). 